\title{
LOGISTICS AND INVENTORY SYSTEMS OF JUST-IN-TIME MANUFACTURING
}

\author{
TAKAKUWA, S.
}

Abstract: The characteristics of logistics and inventory systems for the realization of just-in-time manufacturing are described from the standpoint of management and information systems. First, the methods of implementing just-in-time manufacturing in a factory producing personal computers are detailed. Following this, the inventory control systems adopted in JIT manufacturing are clarified. Finally the methods to supply parts to a company from domestic and international suppliers are highlighted in meeting just-in-time manufacturing in the factory.

Key words: Just-in-time manufacturing, Kanban system, Cell production system, Logistics
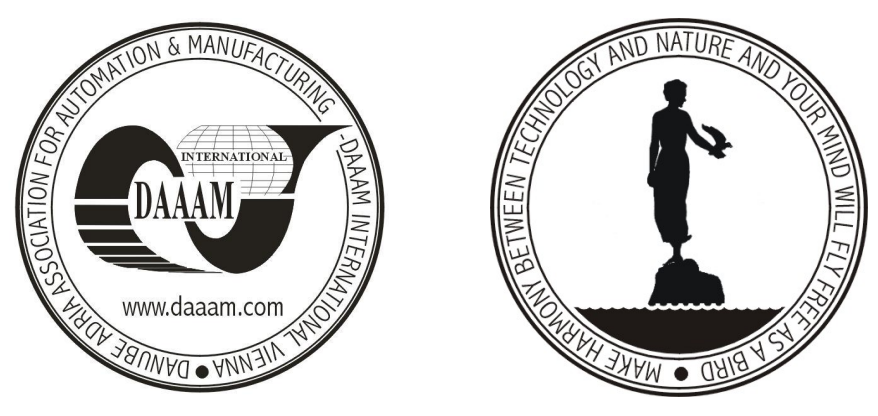

Authors' data: Prof. Takakuwa, S[oemon], Graduate School of Economics and Business Administration, Nagoya University, Furo-cho, Chikusa-ku, Nagoya, Aichi, 464-8601, Japan, takakuwa@soec.nagoya-u.ac.jp

This Publication has to be referred as: Takakuwa, S. (2007). Logistics and Inventory Systems of Just-In-Time Manufacturing, Chapter 38 in DAAAM International Scientific Book 2007, B. Katalinic (Ed.), Published by DAAAM International, ISBN 3-901509-60-7, ISSN 1726-9687, Vienna, Austria DOI: $10.2507 /$ daaam.scibook.2007.38 